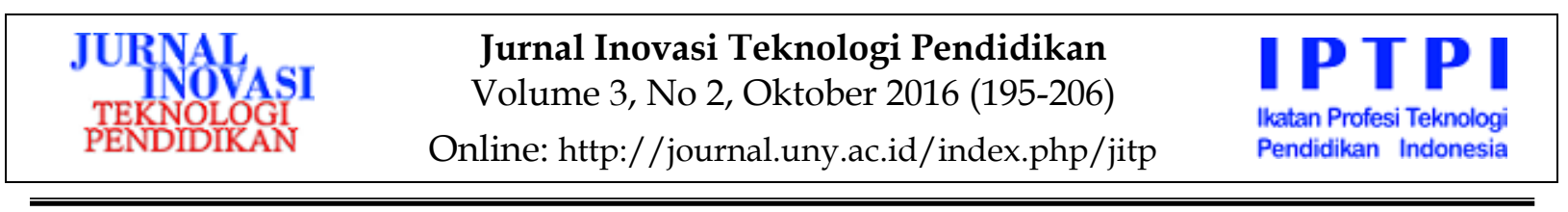

\title{
PENGEMBANGAN E-LEARNING BERBASIS PENDEKATAN ILMIAH PADA MATA PELAJARAN IPA DI SMP NEGERI 5 YOGYAKARTA
}

\author{
Heru Amrul Mu'arif, Herman Dwi Surjono \\ Institut Seni Indonesia Yogyakarta, FT Universitas Negeri Yogyakarta \\ heruamrul@gmail, hermansurjono@uny.ac.id
}

\begin{abstract}
Abstrak
Penelitian ini bertujuan untuk: (1) menghasilkan produk e-learning berbasis pendekatan ilmiah pada mata pelajaran Ilmu Pengetahuan Alam bagi siswa kelas VIII SMP Negeri 5 Yogyakarta dengan spesifikasi model dan isi yang ditetapkan, (2) mengetahui kelayakan produk e-learning, (3) mengetahui hasil belajar siswa setelah menggunakan $e$ learning. Jenis penelitian ini adalah penelitian dan pengembangan $(R \& D)$ dan diadaptasi dari model Alessi dan Trollip. Prosedur pengembangan meliputi tahap perencanaan, desain, dan pengembangan. Hasil Penelitian menunjukan sebagai berikut: (1) produk e-learning berbasis pendekatan ilmiah berhasil dikembangkan dengan sebuah sistem manajemen pembelajaran (LMS) online yang dibuat dengan software aplikasi moodle. E-learning berbasis pendekatan ilmiah dikembangkan untuk pokok bahasan sistem tata surya dan kehidupan di bumi; (2) produk e-learning berbasis pendekatan ilmiah pada mata pelajaran ilmu pengetahuan alam telah memenuhi kriteria dan dinyatakan layak sebagai media pembelajaran berdasarkan validasi ahli media, ahli materi, dan siswa, kelayakannya mencapai rerata skor 4,15 dengan kategori baik; (3) keefektifan pembelajaran IPA lebih baik setelah menggunakan e-learning dibuktikan melalui peningkatan hasil belajar. Hasil belajar siswa kelas VIII SMP Negeri 5 Yogyakarta mengalami peningkatan setelah menggunakan e-learning.
\end{abstract}

Kata kunci: e-learning, pendekatan ilmiah, ilmu pengetahuan alam.

\section{DEVELOPING OF E-LEARNING BASED ON SCIENTIFIC APPROACH ON NATURAL SCIENCES LESSON AT SMPN 5 YOGYAKARTA}

\author{
Heru Amrul Mu'arif, Herman Dwi Surjono \\ Institut Seni Indonesia Yogyakarta, FT Universitas Negeri Yogyakarta \\ heruamrul@gmail, hermansurjono@uny.ac.id
}

\begin{abstract}
This study aims to: (1) develop e-learning based on scientific approaches on natural science subjects for students grade VIII of SMPN 5 Yogyakarta with model specifications and specified contents, (2) determine the feasibility of e-learningproduct (3) determine student learning achievement after using e-learning. This research was a research and development (RED) adapted from models of Alessi ETrollip. The development procedure included the planning, design, and development. This study shows the following results. (1) E-learning-based on scientificapproaches was developed with a learning management system (LMS) online software applications created with Moodle. E-learning is developed based on a scientific approach for the subject of the solar system and life on Earth; (2) e-learning based on scientific approaches for natural science subjects is appropriate as a medium of learning based on the judgement from media expert, materials experts, and students, with the feasibility with mean score of 4.15 with both categories; (3) the learning achievement of class VIII student of SMPN 5 Yogyakarta increases after using e-learning.
\end{abstract}

Keywords: e-learning, scientific approach, natural sciences 


\section{Pendahuluan}

Perkembangan ilmu pengetahuan yang sangat pesat dalam hal teknologi informasi menyebabkan terbuka luasnya area pembelajaran. Perkembangan teknologi informasi juga telah mengubah kondisi pembelajaran yang selalu terikat dengan ruang dan waktu menjadi pembelajaran yang bisa dilaksanakan kapan saja dan dimana saja. Ruang belajar bukan jadi penghalang atau sekat yang membatasi kegiatan siswa dalam belajar. Bahkan dunia merupakan ruang belajar manusia tanpa batas seperti pepatah "The World is The Classroom". Jika aktivitas pembelajaran masih terkendala ruang dan waktu maka akan sangat bertentangan dengan keilmuan teknologi pembelajaran.

Teknologi pembelajaran hadir sebagai solusi dari masalah-masalah yang muncul dalam proses belajar dan pembelajaran. Landasan ontologi timbulnya konsep teknologi pendidikan/pembelajaran antara lain: (1) adanya sejumlah besar orang yang belum terpenuhi kesempatan belajarnya; (2) adanya sumber yang belum dapat dimanfaatkan untuk keperluan belajar; (3) perlu adanya usaha untuk menggarap sumber-sumber tersebut agar dapat terpenuhi hasrat belajar setiap orang; (4) perlunya pengelolaan sumber-sumber belajar agar bisa digunakan secara optimal untuk keperluan belajar (Miarso, 2005, p.166). Sebagai teknolog pembelajaran sudah seharusnya dapat berkontribusi dalam membantu penentu kebijakan mencapai tujuan pendidikan yang diinginkan.

Pada tahun 2013, pemerintah melalui Kementerian Pendidikan dan Kebudayaan pada eranya mulai memberlakukan kurikulum baru guna memperbaharui kurikulum sebelumnya yakni kurikulum tingkat satuan pendidikan (KTSP) menjadi kurikulum 2013. Kurikulum 2013 diberlakukan pada jenjang sekolah dasar hingga menengah.

Kurikulum 2013 mengamanatkan penggunaan pendekatan ilmiah dalam proses pembelajaran sebagaimana tercantum dalam Permendiknas No. 65 Tahun 2013 (Mendikbud, 2013a, p.9) tentang standar proses. Pendekatan ilmiah ini diyakini sebagai sarana yang tepat dalam pengembangan sikap, pengetahuan, dan keterampilan di abad 21. Pada abad 21, siswa tidak hanya dituntut untuk berpengetahuan saja, namun juga dapat memanfaatkan dan mengaplikasikan pengetahuan yang diperoleh untuk kehidupannya kelak.

Proses pembelajaran pada Kurikulum 2013 untuk jenjang SMP dan SMA atau yang sederajat dilaksanakan menggunakan langkah-langkah pendekatan ilmiah termasuk SMP Negeri 5 Yogyakarta. Seluruh mata pelajaran diintegrasikan dengan pendekatan ilmiah termasuk proses pembelajaran mata pelajaran IPA. Proses pembelajaran menyentuh tiga ranah, yaitu sikap, pengetahuan, dan keterampilan. Harapannya hasil akhirnya adalah peningkatan dan keseimbangan antara kemampuan untuk menjadi manusia yang baik (soft skills) dan manusia yang memiliki kecakapan dan pengetahuan untuk hidup secara layak (hard skills) dari siswa yang meliputi aspek kompetensi sikap, keterampilan, dan pengetahuan.

Kurikulum 2013 menekankan pada dimensi pedagogik modern dalam pembelajaran, yaitu menggunakan langkah-langkah pendekatan ilmiah. Langkah-langkah Pendekatan ilmiah dalam pembelajaran sebagaimana dimaksud meliputi mengamati, menanya, menalar, mencoba dan membentuk jejaring atau lebih sering disingkat dengan 5M. Pendekatan ilmiah menjadi pendekatan yang perlu dilaksanakan pada seluruh mata pelajaran untuk jenjang pendidikan menengah, tanpa terkecuali mata pelajaran Ilmu Pengetahuan Alam (IPA).

Pembelajaran IPA pada jenjang Sekolah Dasar dan Menengah bertujuan untuk mengembangkan kemampuan proses ilmiah, mendorong pemahaman konsep dan mengembangkan sikap positif terhadap ilmu pengetahuan. Sikap positif terhadap ilmu pengetahuan membutuhkan 
sumber belajar dan media pembelajaran yang beragam (Surjono, 2013, p.15).

Faktanya sumber belajar dan media pembelajaran yang dapat mendukung kegiatan pembelajaran IPA yang dapat mendukung langkah-langkah pendekatan ilmiah masih sangat terbatas. Sumber belajar yang digunakan masih berupa buku cetak. Siswa dituntut untuk mengakses sumber belajar lainnya melalui internet tanpa kontrol dan acuan yang jelas.

Prasurvei yang dilakukan di SMP

Negeri 5 Yogyakarta kemudian diperoleh hasil identifikasi masalah sebagai berikut, (1) belum optimalnya interaksi pembelajaran; (2) belum adanya media pembelajaran yang tepat dan menarik untuk mengakomodir interaksi pembelajaran IPA yang menggunakan langkah pendekatan ilmiah; (3) pertemuan tatap muka yang terbatas mengakibatkan ada beberapa materi yang sulit untuk dipelajari dengan tatap muka khususnya pada materi yang dipelajari di akhir semeseter; (4) sumber belajar yang terintergrasi dengan kurikulum 2013 dan pendekatan ilmiah masih terbatas sehingga siswa kesulitan untuk melakukan pengamatan; (5) belum optimalnya pemanfaatan fasilitas laboratorium komputer dan jaringan internet dalam mendukung kegiatan pembelajaran IPA; (6) rendahnya hasil belajar siswa kelas VIII SMP Negeri 5 Yogyakarta pada mata pelajaran IPA.

Berdasarkan analisis terhadap kendala dan permasalah yang muncul pada pembelajaran maka diperlukan solusi yang tepat dan bermanfaat agar pembelajaran IPA dapat mencapai tujuan dan kompetensi yang diinginkan. Pembelajaran yang memanfaatkan teknologi dan media pembelajaran serta berbasis pendekatan ilmiah akan memudahkan siswa untuk mengakses sumber belajar dan tujuan pembelajaran akan mudah dicapai. Upaya untuk memberikan akses terhadap sumber belajar yang memadai dapat dilakukan melalui $e$ learning.

E-learning yang kini menjadi sangat populer karena fleksibilitas dan efektivitasnya merupakan cara penyampaian materi pembelajaran yang cukup baik. Melalui $e$ learningdan sumber daya memadai materi pembelajaran dapat diakses kapan saja dan dimana saja (Surjono, 2013, p.19)

Hasil penelitian tentang e-learning (Yuliastuti, Pujayanto, \& Ekawati, 2014, p.1) menujukan bahwa apabila e-learning dikembangkan dengan baik maka dapat digunakan dalam kegiatan belajar tatap muka di kelas, pembelajaran jarak jauh, serta menjadi sarana belajar mandiri bagi siswa

Berdasarkan hasil identifikasi masalah dan solusi yang ditawarkan maka dirumuskan permasalahan yakni, bagaimana produk e-learning berbasis pendekatan ilmiah pada mata pelajaran Ilmu Pengetahuan Alam yang layak dan dapat meningkatkan hasil belajar siswa kelas VIII SMP Negeri 5 Yogyakarta.Adapun tujuan penelitian ini adalah menghasilkan produk $e$ learning berbasis pendekatan ilmiah pada mata pelajaran IPA yang layak dan dapat meningkatkan hasil belajar siswa kelas VIII SMP Negeri 5 Yogyakarta. Melalui e-learning berbasis pendekatan ilmiah diharapkan menjadi solusi terhadap masalah yang terindentifikasi.

Konsep e-learning secara umum yaitu suatu pembelajaran elektronik berbasis web atau TIK yang dibuat dengan prinsip dan metode tertentu sehingga dapat digunakan sebagai media pembelajaran open source yang menarik. Pembelajaran dengan e-learning memungkinkan siswa belajar secara individual, kolaboratif, aktif, konstruktif, kontekstual, reflektif, serta mengasah berfikir tingkat tinggi, baik melalui internet maupun intranet.

Prinsip e-learning menurut Prakoso, (2005, pp.6-7) ada enam macam yaitu: (1) pusat kegiatan peserta didik, e-learning harus bisa sebagai sarana bagi pusat kegiatan siswa dalam menambah kemampuan, membaca, mencari informasi dan sebagainya; (2) interaksi dalam grup, seorang pendidik atau desainer e-learning harus mempersiapkan aplikasi yang bisa menjalin interaksi antara semua komponen yang terlibat dalam pembelajaran; (3) sistem administrasi siswa, e-learning dileng- 
kapi dengan sistem administrasi bagi peserta didik; (4) evaluasi, e-learning harus dilengkapi dengan evaluasi dan lebih baik lagi kalau ada latihannya; (5) perpustakaan digital, peserta dididk dapat mengakses sumber-sumber digital lainya; (6) materi online, siswa dapat mendownload materi yang telah tersedia di e-learning secara gratis. Melalui penerapan prinsip maka keunggulan dan kelebihan pembelajaran yang menggunakan e-learning dapat dicapai .

Kearn (2010, p.6) menyatakan bahwa e-learning memiliki kelebihan yaitu: (1) hemat biaya; (2) fleksibel tempat; (3) pengguna dapat melakkan akses dimana saja, dan kapan saja setiap saat; (4) standardisasi konten antar instruktur diseluruh organsisasi; (5) tugas yang interaktif; (6) kompatibilitas; (7) peserta didik segera mendapat umpan balik; (8) pelacakan kinerja peserta didik mudah diketahui. Elearning juga mempunyai kelemahan karena sangat bergantung dengan jaringan internet.

Pemanfaatan internet untuk pembelajaran atau e-learning juga tidak terlepas dari berbagai kekurangan. Adapun kelemahan e-learning menurut Clarey (2009, p.52), yaitu: (1) kemampuan akses, (2) kecepatan internet, (3) biaya dan waktu pengembangan, (4) keterbatasan pengembangan, (5) tidak semua materi cocok untuk e-learning, (6) butuh motivasi dan inisatif dari peserta didik. E-learning yang baik tentunya harus memenuhi kriteria berdasarkan aspek-aspek yang dinilai

Alessi \& Trollip (2001, p.404) mengemukakan beberapa aspek yang penting untuk dinilai pada media pembelajaran khususnya e-learning. Adapun aspek-aspek tersebut yakni, infomasi tambahan (auxiliary information), pertimbangan sikap pengguna (affective considerations), hubungan pengguna dengan program (interface), navigasi (navigation), pegagogi (pedagogy), fitur tak tampak (invisible features), dan materi tambahan (supplementary materials). E-learning efektif jika dikembangkan dengan basis pendekatan yang digunakan dalam pembelajaran seperti pendekatan ilmiah.

Sagan (1980, p.46) juga mendefinisikan pendekatan ilmiah sebagai suatu upaya untuk mendapatkan pengetahuan, menggambarkan filosofi, menngeneralisasikan pengetahuan berdasarkan fakta, dan menjadi paradigma mendasar didalam sebuah proses pembelajaran. Melalui pembelajaran IPA dengan pendekatan ilmiah, siswa dapat menemukan jawaban dari rasa ingin tahunya serta mengaplikasikan pengetahuannya dalam kehidupan seharihari.

Proses pembelajaran harus dipandu dengan kaidah-kaidah pendekatan ilmiah. Pendekatan ini bercirikan penonjolan dimensi pengamatan, penalaran, penemuan, pengabsahan, dan penjelasan tentang suatu kebenaran. Dengan demikian, proses pembelajaran harus dilaksanakan dengan dipandu nilai-nilai, prinsip-prinsip, atau kriteria ilmiah.

Kurikulum 2013 menekankan pada dimensi pedagogik modern dalam pembelajaran, yaitu menggunakan pendekatan ilmiah. Pendekatan ilmiah (scientific appoach) dalam pembelajaran sebagaimana dimaksud meliputi mengamati, menanya, mencoba, mengolah, menyajikan, menyimpulkan, dan mencipta untuk semua mata pelajaran. Pada mata pelajaran, materi, atau situasi tertentu, sangat mungkin pendekatan ilmiah ini tidak selalu tepat diaplikasikan secara prosedural. Pada kondisi seperti ini, tentu saja proses pembelajaran harus tetap menerapkan nilai-nilai atau sifat-sifat ilmiah dan menghindari nilainilai atau sifat-sifat non ilmiah.

Esensi pendekatan ilmiah yang digunakan pada e-learning nantinya akan membantu peserta didik untuk mengakses banyak sumber dan melaporkan setiap temuan-temuan yang dipelajari kepada pendidik. Interaksi dan forum diskusi yang ada pada e-learning juga memudahkan peserta didik untuk mengeksplore banyak sumber-sumber belajar. Melalui e-learning, langkah dan kegiatan Pendekatan ilmiah bisa diakomodasi. 
Penggunaan pendekatan ini diharapkan dapat membuat pembelajaran menjadi lebih bermakna bagi siswa dan juga untuk meningkatkan kecakapan abad 21, yaitu way of thinking, way of working, tools for working, and living in the world (Brinkley, 2010, pp.1-2). Pendekatan illmiah diyakini dapat mendorong siswa untuk mengembangkan seluruh kemampuannya terutama kecakapan hidup di abad 21, yaitu bagaimana berpikir, bekerja, sebagai suatu alat mendapatkan pekerjaan, dan bagaimana hidup di masyarakat. Jadi, secara tidak langsung siswa sedang diajak untuk merencanakan karir masa depannya. Tentunya karir masa depannya bergantung pada skill dan kompetensi yang ia miliki sejak dibangku sekolah.

Pendekatan ilmiah yang dimaksud merupakan suatu pendekatan dalam proses pembelajaran yang melibatkan aktivitas ilmiah di dalamnya dimana siswa berperan sebagai seorang peneliti yang sedang mencari jawaban dari permasalahan yang dihadapi dalam kegiatan pembelajaran. Pendekatan ilmiah pada e-learning menjadi basis dalam pengembangan materi dan konten yang akan disajikan. Langkah-langkah pendekatan ilmiah diadaptasi untuk menyusun langkah kegiatan pembelajaran IPA menggunakan e-learning.

Pembelajaran mata pelajaran IPA lebih menekankan pada pengalaman langsung untuk mengembangkan kompotensi agar peserta didik mampu memahami alam sekitar melalui proses "mencari tahu dan berbuat", hal ini akan membantu peserta didik untuk memperoleh pemahaman yang lebih mendalam. Melalui $e$ learning berbasis pendekatn ilmiah, pembelajaran IPA akan dilakukan dengan: (1) memberikan proses pengalaman pada peserta didik sehingga siswa menguasai materi yang dipelajari; (2) menanamkan peserta didik pentingnya pengamatan empiris dalam menguji suatu pernyataan ilmiah (hipotesis); (3) memberikan akses sebesar besarnya untuk mencari sumbersumber belajar melalui media pembelajaran seperti e-learning; dan (4) memper- kenalkan dunia teknologi melalui kegiatan kreatif dalam kegiatan perancangan dan pembuatan alat-alat sederhana maupun penjelasan berbagai gejala dalam keilmuan ipa serta menjawab berbagai masalah yang dialami siswa sehari-hari.

Materi pelajaran sebagai konten yang dikembangkan harus dikelola sesuai sesuai dengan karakteristik peserta didik sebagai calon pengguna produk. Implementasi nyata dari kajian mengenai karakteristik peserta didik terhadap e-learning yang dikembangkan dapat dilihat dari penentuan sasaran pengguna, desain layout yang akan digunakan, materi yang disajikan, umpan balik yang diberikan, gambar, video dan penggunaan kalimat yang mudah dipahami oleh calon pengguna.

\section{Metode Penelitian}

Penelitian ini merupakan penelitian pengembangan atau dikenal dengan istilah Research and Development $(R \mathcal{E} D)$, yang menghasilkan sebuah produk berupa $e$ learning berbasis pendekatan ilmiah pada mata pelajaran Ilmu Pengetahuan Alam bagi siswa kelas VIII SMP Negeri 5 Yogyakarta.

Waktu penelitian dimulai dari bulan Maret hingga Juni 2015. Lokasi penelitian atau uji coba produk yakni di SMP Negeri 5 Yogyakarta. Pada pelaksanaannya uji coba dilakukan secara bertahap sebanyak 4 kali pertemuan.

Target/sasaran penelitian dan uji coba produk yakni siswa kelas VIII SMP Negeri 5 Yogyakarta. Subjek atau responden yang terlibat dalam penelitian ini adalah siswa kelas VIII SMP Negeri 5 Yogyakarta. Penetapan subjek berdasarkan pertimbangan bahwa materi yang diajarkan sesuai dengan analisis kebutuhan dan pelajaran pada semester II. Untuk lebih jelasnya subjek uji coba sebagai berikut: (1) subjek untuk analisis kebutuhan yang terdiri dari 33 orang siswa kelas VIII SMP Negeri 5 Yogyakarta dengan pertimbangan bahwa hasil rekapitulasi nilai UAS Semester 1 menunjukkan bahwa kelas terse- 
but masih memperoleh nilai di bawah ratarata yang sudah ditetapkan sekolah dan kelas lainnya, (2) Subjek untuk uji coba test alpha dilakukan oleh ahli media dan Media yang terdiri dari 2 Ahli Materi dan 2 Ahli Media dengan dasar pertimbangan bahwa Ahli media dan materi tidak berkeberatan, berkompeten dibidangnya dan bersedia menilai instrumen. Ahli materi terdiri dari 1 dosen dan 1 guru mata pelajaran IPA; (3) subjek ujicoba tes beta dilakukan oleh 30 orang siswa kelas VIII SMP Negeri 5 Yogyakarta yang dipilih secara acak dengan dasar pertimbangan tidak mengganggu proses pembelajaran dan bersedia dalam menguji produk; dan (4) Subjek dalam penilaian sumatif (produk final) melibatkan 30 orang siswa kelas VIII SMP Negeri 5 Yogyakarta yang dipilih secara acak dengan dasar pertimbangan tidak menggangu proses pembelajaran.

Prosedur pengembangan e-learning berbasis pendekatan ilmiah mata pelajaran IPA kelas VIII SMP Negeri 5 Yogyakarta, diadaptasi dari prosedur pengembangan yang sudah dikembangkan oleh Alessi dan Trollip yang kemudian oleh peneliti disesuaikan dengan kemampuan dan keterbatasan penelitian. Sebelum melakukan pengembangan untuk menentukan karakteristik materi dan karakteristik pengguna, peneliti telah melakukan analisis kebutuhan terlebih dahulu. Analisis ini mengacu pada kurikulum 2013 yang digunakan pada jenjang SMP, Khususnya SMP Negeri 5 Yogyakarta.

Model pengembangan ini memiliki tiga atribut dan tiga fase, tiga fase tersebut meliputi standard, ongoing evaluation, dan project management. Sedangkan tiga fase meliputi perencanaan (planning), desain (design) dan pengembangan (development).

Data yang diperoleh dalam penelitian ini merupakan data kualitatif dan kuantitatif. Data kualitatif didapat dari uji coba produk e-learning. Data kuantitatif didapat dari ahli media dan ahli materi (uji alpha) juga dari siswa (uji beta). Data tersebut dibutuhkan agar nantinya dapat memberikan gambaran mengenai kelayakan e-learning dan kualitas teknik tampilan produk serta peningkatan pemahaman siswa setelah menggunakan produk $e$ learning.

Instrumen yang digunakan untuk penelitian dikembangkan dari aspek-aspek penilaian e-learning yang dikemukakan Allesi dan Trollip (2001, p.401) serta didukung oleh pendapat Attwell (2006, p.43) melalui kriteria penilaian e-learning. Instrumen yang digunakan untuk penelitian terlebih dahulu dilakukan validasi oleh ahli instrumen.

Validasi instrument meliputi penentuan expert judgement ahli media, ahli materi, dan siswa. Validasi yang dilakukan berupa validitas konstruk ahli media dan ahli materi. Validasi instrumen dilakukan oleh validator instrumen.

Data yang diperoleh pada saat prasurvei dan analalsismelalui guru, analisis kebutuhan siswa dan laboran IPA dipakai dalam menentukan ide awal pengembangan e-learning berbasis pendekatan ilmiah pada mata pelajaran IPA. Selain itu saran dari ahli media, ahli materi, dan siswa dihimpun dan dianalisis untuk memperbaiki e-learning berbasis pendekatan ilmiah pada mata pelajaran IPA.

Tabel 1. Konversi Data Penilaian Produk E-learning

\begin{tabular}{cccc}
\hline \multirow{2}{*}{ Nilai } & Kriteria & \multicolumn{2}{c}{ Skor } \\
\cline { 3 - 4 } A & Sangatbaik & Rumus & Perhitungan \\
B & Baik & $X i+0,6 S b i<X \leq X i+1,8 S b i$ & $X>4,21$ \\
C & Cukupbaik & $X i-0,6 S b i<X \leq X i+0,6 S b i$ & $3,40<X \leq 4,21$ \\
D & Kurang & $X i-1,8 S b i<X \leq X i-0,6 S b i$ & $2,60<X \leq 3,40$ \\
E & Sangatkurang & $X \leq X i-1,8 S b i$ & $1,79<X \leq 2,60$ \\
\end{tabular}


Data yang diperoleh dari validasi ahli media, materi, dan tanggapan siswa dianalisis menggunakan statistik deskriptif kemudian dikonversi ke dalam data " 5 " (Sukardjo, 2006, p.53). Konversi data untuk menentukan kategori penilaian dapat dilihat pada Tabel 1.

\section{Hasil Penelitian dan Pembahasan}

Produk yang dihasilkan dalam penelitian ini adalah e-learning berbasis pendekatan ilmiah pada mata pelajaran Ilmu Pengetahuan Alam. Pendekatan ilmiah yang menjadi basis produk e-learning dapat diketahui melalui implementasinya dari kurikulum, sajian materi, pengelolaan materi dan langkah pembelajaran yang digunakan. E-learning dapat diakses melalui situs marbelscience.web.id. Tampilan depan portal e-learning dapat dilihat melalui Gambar 1.

Setelah e-learning dikembangkan maka dilanjutkan dengan validasi oleh 2 orang ahli materi dan 2 orang ahli media. Validasi dilakukan untuk memperoleh penilaian terhadap e-learning. Adapun hasil penilaian oleh kedua ahli materi dapat diketahui melalui Gambar 3.
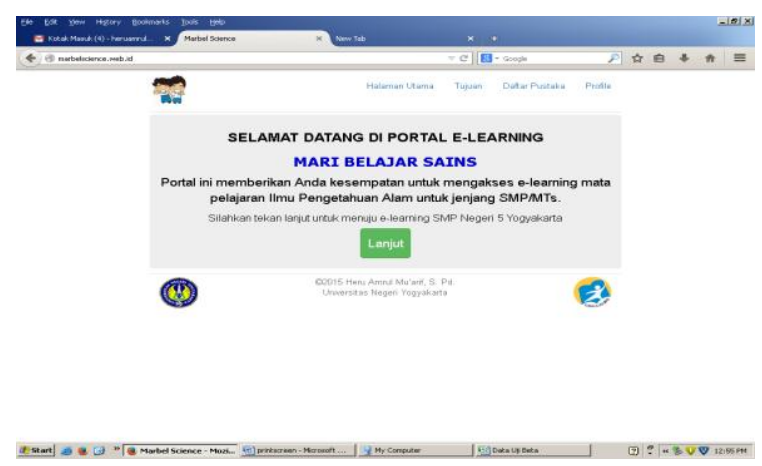

Gambar 1. Tampilan Portal E-learning

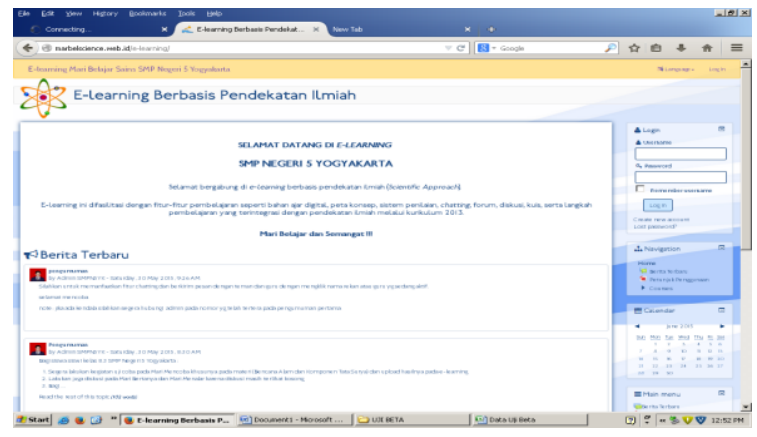

Gambar 2. Tampilan Depan E-learning

Penilaian ahli materi 1 terhadap seluruh indikator/aspek yang divalidasi diperoleh rata-rata penilaian sebesar 4,1 dengan kategori "Baik" dan dinyatakan layak untuk diujikan pada tahap berikutnya.

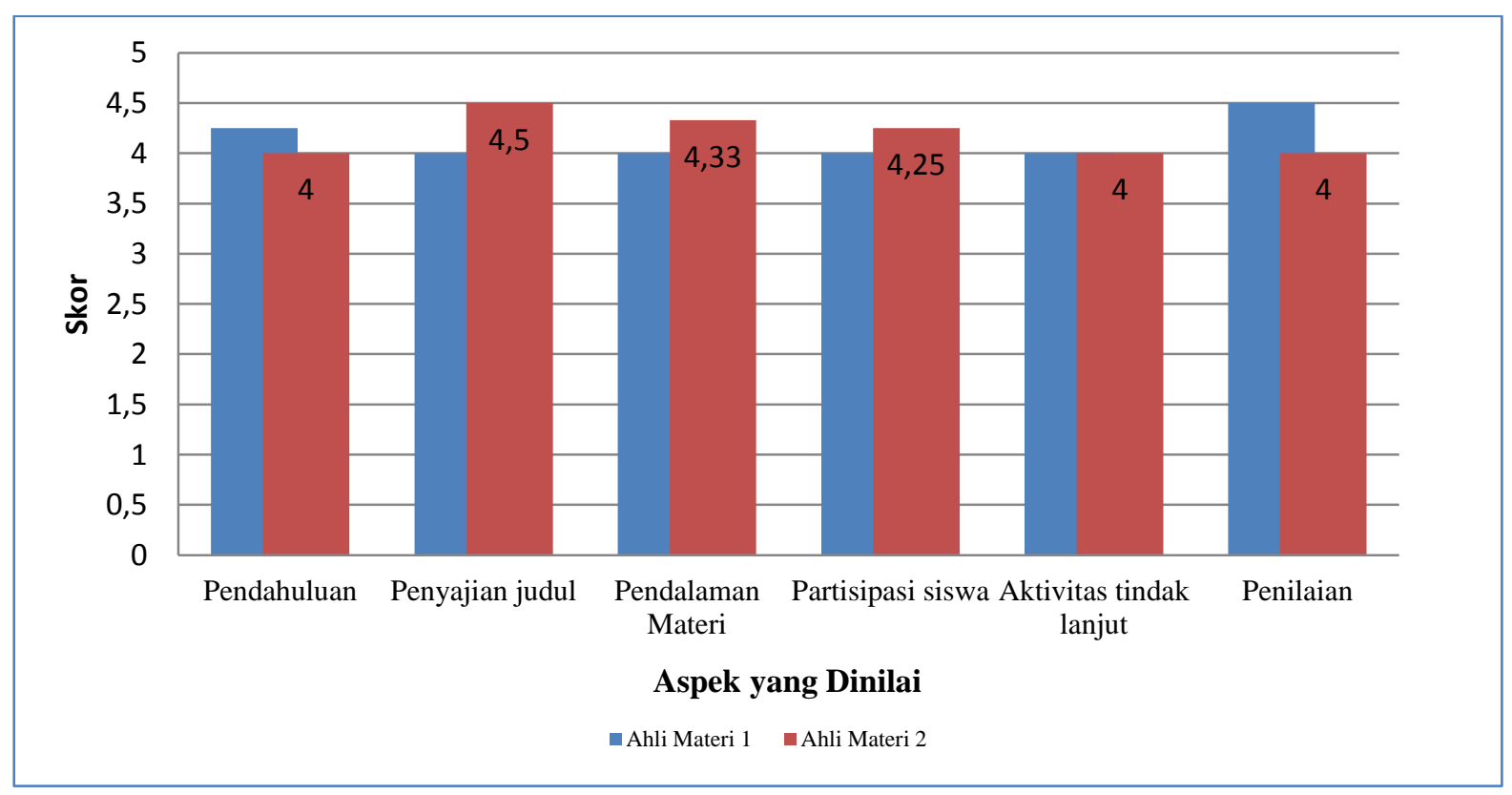

Gambar 3. Hasil Penilaian Ahli Media 
Adapun hasil penilaian oleh kedua ahli media dapat diketahui melalui gambar 4.

Hasil validasi/uji alpha yang dilakukan oleh ahli media 1 diperoleh ratarata penilaian yakni 3,91 dengan kategori "Baik" dan dinyatakan "Layak" serta dapat dilakukan uji coba berikutnya. Hasil validasi oleh ahli media 2 diperoleh ratarata penilaian 4,52 dengan kategori "Sangat Baik" dan dinyatakan "Layak" serta dapat dilakukan uji coba berikutnya. Langkah berikutnya adalah uji beta yang dilakukan oleh siswa sebagai calon pengguna.
Uji beta atau tes beta merupakan tes akhir yang sepenuhnya dilakukan oleh siswa sebagai peserta uji coba. Uji beta dilakukan secara formal dengan prosedur pembelajaran yang telah disepakati pada rencana pelaksanaan pembelajaran. Uji beta dilakukan secara bertahap sebanyak 4 kali pertemuan. Peserta yang melakukan uji beta berjumlah 34 siswa yang terdiri dari siswa kelas VIII.3 SMP Negeri 5 Yogyakarta. Hasil analisis data uji beta dapat diketahui melalui Tabel 2.

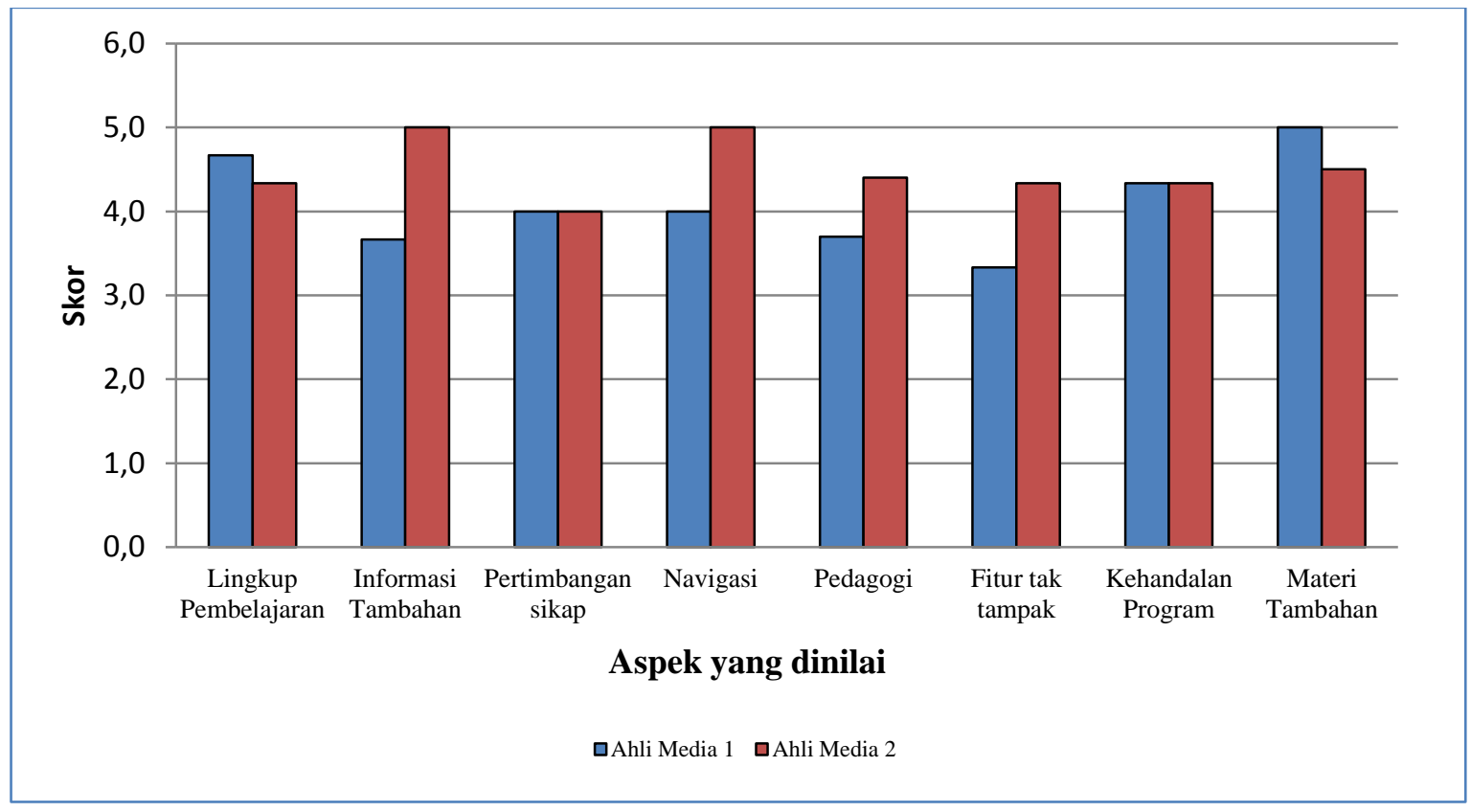

Gambar 4. Hasil Penilaian Ahli Media

Tabel 2. Hasil analsis data uji beta

\begin{tabular}{clccc}
\hline No & Aspek/Indikator yang divalidasi & Nilai & Rata-Rata & Kriteria \\
\hline 1 & Daya tarik produk & 140 & 4,12 & Baik \\
2 & Kedalaman Materi & 130 & 3,82 & Baik \\
3 & Motivasi & 134 & 3,94 & Baik \\
4 & Dukungan Terhadap Belajar & 142 & 4,18 & Baik \\
5 & Waktu dan Kesempatan Belajar & 133 & 3,91 & Baik \\
6 & Tampilan dan Bahan yang Ditampilkan & 139 & 4,09 & Baik \\
7 & Kemudahan akses & 133 & 3,91 & Baik \\
8 & Konsistensi tampilan dan navigasi & 133 & 3,91 & Baik \\
9 & Fasilitas interaksi & 148 & 4,35 & Sangat Baik \\
10 & Kesesuaian materi dengan kehidupan & 134 & 3,94 & Baik \\
Jumlah & & 1366 & 40,17 & \\
Rata-rata & 136,6 & 4,07 & Baik \\
\hline
\end{tabular}


Berdasarkan hasil rekapitulasi data uji beta terhadap e-learning berbasis pendekatan ilmiah diperoleh rata-rata penilaian 4,07. Hasil analisis terhadap data dan persentase hasil penilaian subjek coba pada uji beta diketahui bahwa kualitas e-learning berbasis pendekatan ilmiah mata pelajaran IPA bagi siswa kelas VIII SMP Negeri 5 Yogyakarta termasuk kategori baik dan layak untuk digunakan pada proses pembelajaran.

Evaluasi sumatif dilakukan untuk mengetahui hasil belajar siswa setelah menggunakan e-learning berbasis pendekatan ilmiah. Evaluasi dilakukan dalam bentuk pretest dan posttest. Pretestdilakukan pada pertemuan awal yakni pada tanggal 22 Mei 2015 sebelum siswa memperoleh materi menggunakan e-learning. Posttest dilakukan pada pertemuan terakhir yakni pada tanggal 29 Mei 2015 atau setelah siswa memperoleh materi dan belajar menggunakan e-learning. Pretest dan posttest diberikan kepada kelas VIII 3 SMP Negeri 5 Yogyakarta sebagai subjek coba penggunaan e-learning. Adapun hasil belajar siswa dalam bentuk uji kompetensi yang diperoleh melalui posttest dan pretest dapat dilihat pada Tabel 3.

Berdasarkan analisis terhadap hasil belajar siswa kelas VIII.3 SMP Negeri 5 Yogyakarta diperoleh rata-rata pretest 78,82 dan rata-rata posttest 94,41. Setelah dianalisa tedapat selisih rata-rata sebesar 15,59 . Data hasil belajar ini menjadi rekomendasi bagi pengembang untuk menyimpulkan bahwa e-learning berbasis pendekatan ilmiah dapat meningkatkan hasil belajar siswa.
Tabel 3. Hasil Analisis Data Evaluasi Sumatif.

\begin{tabular}{ccc}
\hline \multirow{2}{*}{ Data } & \multicolumn{2}{c}{ Nilai } \\
& Pretest & Postest \\
\hline NilaiTertinggi & 90 & 100 \\
NilaiTerendah & 65 & 80 \\
Jumlah & 2680 & 3210 \\
Rata-Rata & 78,82 & 94,41 \\
Gain & \multicolumn{2}{c}{15,59} \\
\hline
\end{tabular}

Pada saat dilaksanakan uji beta peneliti juga melakukan pengamatan terhadap reaksi dan sikap pengguna e-learning melalui laporan aktivitas pengguna dari aplikasi moodle. Aplikasi moodle memberikan laporan aktivitas berdasarkan intensitas keaktifan siswa dari forum, chatt, dan Quiz (uji kompetensi). Penilaian juga dilakukan ketika siswa menggunakan secara langsung e-learning pada pertemuan tatap muka. Penilaian pengamatan reaksi dan sikap pengguna terhadap e-learning diperoleh dari penilaian terhadap beberapa aspek meliputi, antusiasme, kemudahan dalam menggunakan media, respon postif, rasa ingin tahu, sikap aktif. Adapun hasil analisis penilaian terhadap reaksi dan sikap dapat dilihat pada Tabel 4.

Respon yang positif ditunjukan oleh siswa terhadap e-learning diketahui dari hasil pengamatan selama penggunaan e-leaning diperoleh rata-rata 4,28 dengan katerogi baik. Dengan demikian, e-learning berbasisi pendekatan ilmiah dinilai sebagai media pembelajaran yang valid dan layak untuk digunakan pada pembelajan IPA khususnya bagi jenjang kelas VIII SMP Negeri 5 Yogyakarta.

Tabel 4. Hasil Analisis Penilaian terhadap Reaksi dan Sikap Pengguna

\begin{tabular}{clcc}
\hline No & \multicolumn{1}{c}{ Aspek yang diamati } & Nilai & Rata-rata \\
\hline 1 & Antusiasme & 147 & 4,32 \\
2 & Kemudahan dalam menggunakan media & 148 & 4,35 \\
3 & Respon Postif & 142 & 4,17 \\
4 & Rasa Ingin Tahu & 143 & 4,2 \\
5 & Sikap Aktif & 148 & 4,35 \\
Jumlah & 728 & 21,39 \\
Rata-Rata & 145,6 & 4,27 \\
Kategori & \multicolumn{2}{c}{ Baik } \\
\hline
\end{tabular}




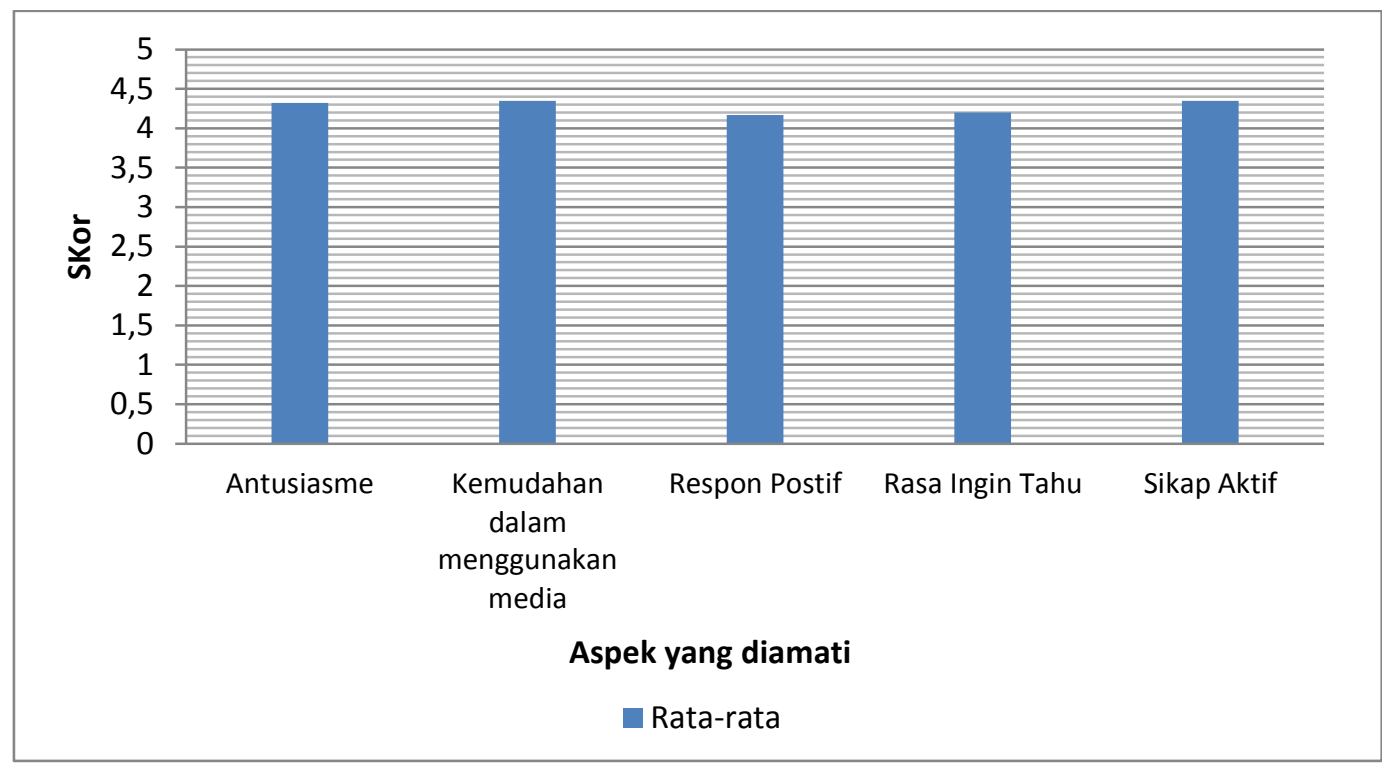

Gambar 5. Hasil Penilaian Reaksi dan Sikap Pengguna

E-learning berbasis ilmiah dikembangkan atas dasar kebutuhan salah satu sekolah yakni SMP Negeri 5 Yogyakarta.

Berdasarkan analisis kebutuhan di SMP Negeri 5 Yogyakarta diperoleh informasi dan data yang menguatkan peneliti untuk mengembangkan sebuah media berupa e-learning.

Pengembangan e-learning berbasis pendekatan ilmiah dilakukan sejak bulan april sampai bulan juni 2015 (tiga bulan). Pengembangan e-learning berbasis pendekatan ilmiah berupa portal e-learning dengan menggunakan aplikasi editing web dreamweaver dan LMS (Learning Management System) melalui aplikasi moodle. Moodle merupakan perangkat lunak open source yang mendukung implementasi $e$ learning.

E-learning yang dikembangkan juga dikaitkan dengan penerapan kuri-kulum 2013. Penerapan kurikulum 2013 erat kaitannya dengan pendekatan ilmiah pada seluruh mata pelajaran termasuk ilmu pengetahuan alam. Melalui e-learning berbasis pendekatan ilmiah ini siswa SMP Negeri 5 Yogyakarta dapat mengakses materi yang diinginkan khususnya materi yang dikembangkan dalam bentuk digital.

Portal e-learning yang diberi identitas mari belajar sains ini dapat diakses siswa melalui internet dimana saja dan kapan saja dengan URL marbelscience.web.id. Cakupan materi $e$ learning meliputi materi mata pelajaran Ilmu Pengetahuan Alam kelas VIII semester genap dengan pokok bahasan Sistem Tata Surya dan Kehidupan di Bumi. Elearning bersera konten yang diupload pada e-learning telah melalui validasi oleh ahli materi dan ahli media, serta telah mengikuti tahap-tahap dalam pengembangan.

Pada tahap uji alpha, e-learning berbasis pendekatan ilmiah divalidasi oleh 4 orang ahli yang meliputi 2 orang ahli materi dan 2 orang ahli media. Validasi oleh kedua ahli materi dilakukan mulai tanggal 18 Mei sampai 26 Mei 2015. Penilaian ahli materi 1 terhadap seluruh indikator/aspek yang divalidasi diperoleh rata-rata penilaian sebesar 4,1 dengan kategori "Baik" dan dinyatakan layak digunakan dan telah direvisi sesuai saran. Penilaian ahli materi 2 terhadap seluruh indikator/aspek yang divalidasi diperoleh rata-rata penilaian sebesar 4,2 dengan kategori "Sangat Baik" dan dinyatakan layak dan telah direvisi sesuai saran.

Validasi oleh kedua ahli media dilakukan mulai tanggal 19 Mei sampai 23 Mei 2015. Hasil validasi/uji alpha yang 
dilakukan oleh ahli media 1 diperoleh ratarata penilaian yakni 3,91 dengan kategori "Baik" dan dinyatakan layak serta telah direvisi sesuai saran. Hasil penilaian oleh ahli media 2 diperoleh rata-rata penilaian 4,52 dengan kategori "Sangat Baik" dan dinyatakan layak serta telah direvisi sesuai saran.

Pada tahap uji beta, e-learning berbasis pendekatan ilmiah telah diujicobakan pada 34 peserta yang berasal dari kelas VIII.3 SMP Negeri 5 Yogyakarta. Uji coba dilakukan mulai tanggal 23 Mei sampai tanggal 29 Mei 2015. Pada akhir pertemuan dilakukan penilaian terhadap produk $e$ learning ini dan diperoleh rata-rata penilaian sebesar 4,07 dengan kategori baik serta dinyatakan layak digunakan dalam proses pembelajaran.

Pengukuran hasil uji belajar melalui pemberian pretest dan posttest pada evaluasi sumatif dilakukan juga pada 34 siswa kelas VIII.3 SMP Negeri 5 Yogyakarta. Pretest dilakukan pada saat sebelum siswa menggunakan atau mengakses elearning yakni pada tanggal 20 Mei 2015. Sedangkan posttes dilakukan setelah siswa mengunakan atau mengakses e-learning yakni pada tanggal 29 Mei 2015. Hasil pretest kemudian dibandingkan dengan hasil posttest untuk diperoleh data hasil belajar. Berdasarkan analisis terhadap hasil prettest dan posttest diketahui adanya kenaikan hasil belajar setelah menggunakan e-learning sebesar 15,58\%. Efek positif dari kenaikan hasil belajar tersebut yakni pembelajaran IPA kelas VIII Semester genap menggunakan e-learning berbasis pendekatan ilmiah dapat meningkatkan kompetensi kognitif dan pemahaman konsep.

Nilai fleksibilitas e-learning dapat dilihat dari dokumentasi pada lampiran 25, kegiatan yang menunjukan bahwa siswa bisa mengakses dimana saja, kapan saja tanpa harus terikat waktu dan jam pelajaran tatap muka. E-learning berbasis pendekatan ilmiah mendapat respon baik dari sekolah, guru mata pelajaran dan siswa sebagai pengguna. Respon yang positif ditunjukan oleh siswa terhadap e-learning diketahui dari hasil pengamatan selama penggunaan e-leaning diperoleh rata-rata 4,28 dengan katerogi baik. Dengan demikian, e-learning berbasisi pendekatan ilmiah dinilai sebagai media pembelajaran yang valid dan layak untuk digunakan pada pembelajan IPA khususnya bagi jenjang kelas VIII SMP Negeri 5 Yogyakarta.

Adapun keterbatasan dalam penelitian ini (1) penerapan e-learning dalam pembelajaran akan lebih efektif jika dilaksanakan dengan pertemuan pembelajaran lebih banyak, minimal tiga kali pertemuan. Namun, dalam penelitian dan pengembangan ini peneliti mengalami kesulitan dalam mengatur alokasi waktu pembelajaran karena terkait masa studi peneliti, (2) instrumen ranah keterampilan dalam penelitian ini belum dikembangankan karena tidak termasuk dalam analisis data atau pembahasan. Hal ini dikarenakan keterbatasan waktu peneliti dan fokus peneliti; (3) penelitian dan pengembangan hanya dilakukan sampai tahap uji coba dan tes sumatif, sedangkan uji coba dengan skala luas belum bisa dilakukan karena keterbatasan dana dan waktu peneliti; (4) subjek uji coba dalam penelitian dan pengembangan yang terbatas, menyebabkan tidak semua populasi siswa di SMP pilot project Kurikum 2013 di Yogyakarta dapat diuji coba. Jumlah populasi yang semakin banyak dan bervariasi dapat memberikan informasi tambahan terkait temuan-temuan lapangan yang dapat digunakan untuk menyempurnakan e-learning yang dikembangkan.

\section{Simpulan dan Saran}

\section{Simpulan}

Berdasarkan hasil analisis data dan pembahasan dapat disimpulkan sebagai berikut. Hasil penelitian dan pengembangan berupa produk e-learning berbasis pendekatan ilmiah pada mata pelajaran Ilmu Pengetahuan Alam bagi siswa kelas VIII SMP Negeri 5 Yogyakarta. Software yang digunakan untuk mengembangkan e-learn- 
ing ini menggunakan moodle. Fitur yang ada pada aplikasi moodle berupa forum, chat, sajian materi, dan penilaian disesuaikan dengan langkah pendekatan ilmiah. Produk e-learning berbasis pendekatan ilmiah telah layak sesuai kriteria yang ditentukan berdasarkan hasil uji alpha dan uji beta dan seluruh rangkaian kegiatan penelitian dan pengembangan. Hasil belajar yang diketahui melalui evaluasi sumatif terhadap penggunaan e-learning berbasis pendekatan ilmiah pada mata pelajaran IPA di SMP Negeri 5 Yog-yakarta menunjukkan bahwa terdapat peningkatan pencapaian hasil belajar siswa sebesar $15,58 \%$. Nilai rata-rata pretest 78,82 meningkat pada posttest menjadi 94,41 dengan persentase ketuntasan belajar siswa $100 \%$

Saran

Produk e-learning berbasis pendekatan ilmiah ini perlu implementasi lebih lanjut agar diketahui kelemahan dan kekurangannya dalam proses pembelajaran, materi yang disajikan di e-learning tidak hanya mata pelajaran IPA tetapi mata pelajaran lainnya yang basis kurikulumnya 2013, Selain itu pendidik/guru diharapkan mampu memanfaatkan e-learning ini untuk meningkatkan hasil belajar siswa.

\section{Daftar Pustaka}

Alessi, M.S. \& Trollip, R.S. (2001). Multimedia for learning, methods and development. United States: Pearson Education Inc.

Attwell, G. (2006). Evaluating e-learning; A guide to the evaluation of $e$ learning (3thed). Bremen: Druck Perspektiven Offset.

Brinkley, M. (2010). Defining 21 ${ }^{\text {st }}$ century skills. Diambil pada tanggal 20 Maret 2014, dari http://atc21s.org/wpcontent/uploads/2011/11/1Defining-21st-Century-Skills.pdf, 1 2(20), 52 .
Clarey, J. (2009). E-learning 101: An intriduction to e-learning, learning tools, and technologies. Brandon Hall Research.

Kearn, S.K. (2010). E-learning in avation. England: Ashghate Publising Limited.

Miarso, Y. (2005). Menyemai benih teknologi pendidikan. Jakarta: Prenata Media.

Prakoso, K. S. (2005). Membangun elearning dengan moodle. Yogyakarta: Andi.

Peraturan Menteri Pendidikan dan Kebudayaan Republik Indonesia Nomor 65 Tahun 2013 tentang Standar Proses Pendidikan Dasar Dan Menengah

Sagan, C. (1980). The Scientific Approach. Diambil pada tanggal 30 Oktober 2013,

http://www.sagepub.com/upm132355_chapter2.pdf

Smaldino, dkk. (2005). Instructional technology and media for learning ( $8^{\text {thed }}$ ). New Jersey: Merrill prentice Hall.

Sukardjo. (2006). Kumpulan Materi Evaluasi Pembelajaran. Yogyakarta: UNY Press.

Surjono, H. D.(2013). Membangun course e-learning berbasis moodle-2rd.Ed. Yogyakarta: UNY Press.

Yuliastuti, N., Pujayanto, \& Ekawati, E. Y. (2014). Pengembangan media pembelajaran ipa terpadu berbasis e-learning dengan moodle untuk siswa sekolah menengah pertama pada tema pengelolaan sampah. Jurnal Pendidikan Fisika., 2(1), 1520 Retrieved from http://jurnal.fkip.uns.ac.id/index. php/pfisika/article/view/3730/26 13. 
Pengembangan E-Learning Berbasis Pendekatan Ilmiah ...

Heru Amrul Mu'arif, Herman Dwi Surjono 